\title{
IDEAS AND EXPERIENCE
}

\author{
Jiın Tuedio
}

Erazim Kohak: Idea and Experience: Edmund Iusser1's Project of phenomenology in Ideas I. pp. xiv +249 .

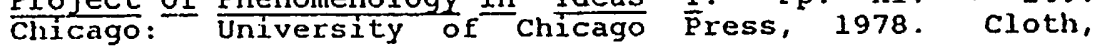
$\$ 17.95$.

Any serious student of Epistemology must eventually come to grips with the epistemological project set forth in Edmund Husserl's Ideen (Ideas) of 1913. After all, Husserl may well have been the very last of his breed. This is certainly true if one is inclined to treat Hegel as the last of the Metaphysicians. For Husserl overcame epistemological dualism in as grand and complete a manner as Hegel had overcome metaphysical dualism. Each, from his own perspective, argued for the ultimate intelligibility of Reality by man-the-experiencer (viewed, of course, as capax veritatis). Thus, whether or not Husserl or Hegel succeeded or failed to close the question regarding the relation between "subjects" and "objects," each seems at least to have brought his respective philosophical project to its ultimate fruition. Erazim Kohak has sought, in his Idea and Experience, to account: for Husserl's success. As an addition to the growing wealth of Husserlian scholarship, it is perhaps the best commentary one could hope for: Although not designed for philosophical laymen, it is well-tailored for phenomenological laymen. The terminology is wellillustrated with appeals to everyday experience, and the fundamental themes of Husserl's thinking (often obscured in the original by sheer verbosity and unfathomable introductions of terminology) are presented with amazing clarity. Indeed, the project of Kolnak's Idea and Experience so mirrors Husserl's own project in the Ideen (as well a commentary's project ought to) that the Husserlian themes become the very themes of Kohak's commentary. Thus Kohak's book is not merely a commentary, but equaliy well an attempt to think in the style and spirit of Husserlian phenomenology. And this means that his project is not one of paraphrasing; rather, Kohak sets out to uncover within experience the various foundations for Husserl's insights into the nature of our capacity for apodictic knowledge. In the process, he arrives at a 
surprisingly high number of very helpful examples. For not only do they present the reader with a compact vision of Husserl's meaning, they also make it almost unavoidable to raise questions which threaten the very project of classical/Modern Epistemology which Husserl's Phenomenology sought to complete. This built-in impetus to raise questions which both Kohak and Husserl fail to postulate may well end up being the ultimate merit of Idea and Experience.

If we take Kohak seriously, we must recognize that although Husserl was infatuated with the spirit of Cartesian thinking, his principal endeavor was to effect a radical synthesis of Humean empiricism and Kantian idealism. For Hume, of course, experience is the point of departure which alone can be utilized in our attempt to account for the human's capacity to grasp principles (Wesen). But "experience" for Hume includes nothing more than the mere perception of particulars: thus we can have no knowledge of reality structured by a notion of eternal validity. Kant, on the other hand, wants to argue that while we must take as our point of departure the "sensory given," experience arises only after our application of the categories. Thus, not only is experience postjudgmental, it is equally well subject-dependent; without the transcendental unity of apperception, there can be no order or regularity in Nature, nor even the possibility of knowing an object in experience (Critique of Pure Reason, A 125-6). For Hume, then, there can be no experience of principles, no "having" or Ideas (Eidos). Ideas and Experience are totaliy incompatible. Kant, on the other hand, does indeed recognize the compatibility of Ideas and Experience, though for him each is mind-dependent. Husserl's project, according to Kohak, is to advance an argument which will account for two things: the primacy of reality as experiential, and the fundamental subjectdimension which makes reality and experience intelligible. Husserl feels we have to start with experience because it alone makes entities intelligible, but we can only understand experience if we "recognize the fundamental Iorientation of its intelligibility" (Kohak, p. 45). It is, then, the subject-function which "constitutes" experience as an intelligible system. But because reality is fundamentally experiential, we do not impose categories which order and regulate the sensory givens of perception; rather, experience is given to us (and indeed presents itself) as making sense. Ideas, then, are not in the mind, "but there in experience. But "experience" means a great deal more to Husserl than grasping particulars via sense perception. This would be experience as Erfahrung. He needs instead to ground knowledge in Erlebnis, the 
"subjectively lived process of consciousness" which "includes patterns and principles as well as particulars." And here the traditional categories of subject and object simply do not apply. For without the human's purposive, intentional orientation, there can be no "grasping," no "seeing.". And yet, there can be no "seeing" without the presence of an object. Each is co-primordial, arising as correlative aspects of a single context, experience. As Kohak remarks,

both common-sense reflection and the sciences based on it tend to overlook that reality as experience is always structured with reference to a subject who lives it and is aware of living it. Lived experiences neutraily as discrete givens. They always fit together in the unity of a subject's experience.

Thus two ship-wrecked survivors who killed a third member in the life-boat for his canteen of water were not after some neutral object we all call "water." Rather,

they killed him for what really was a supremely valuable object-in-experience. Water-worth-a-life is not simply a survivor's "subjective impression" of an "objectively" worthless entity. Rather, it is a different kind of entity whose being is not physical or mental but experiential. (Kohak, pp. 58 and 55, my emphasis)

The point here is that the water is not "judged" to be worth-a-life, but is grasped as being worth-a-life. The water is literally seen (within the intentional orientation) as the meaning-entity water-worth-a-life. And gua "object," the water can be real in no other way. No more talk, in other words, about two-tiered realities:

In our ordinary experience, appearance does not function as a mental double, hiding and hinting at an unseen reality. Here appearance is reality appearing, the real object presenting itself in experience. speculation aside, in ordinary experience to be real means to appear as real in someone's experience. (Kohak, pp. 50-5.1)

But by this Husserl does not mean to suggest that experience and meaning are private (and thus arbitrary). on the contrary, as Kohak correctly remarks, Husserl is "pointing out that it is the presence of subjects-subjects as such, including you and me but not you or me in particular--that gives to whatever there may be the unity and meaning of a reality" (Kohak, p. 104). Of course, to preserve Husseri's stand against Kantian idealism and epistemological dualism, Kohak must add, in 
the same breath, that "the contents of our experience acquire the status and force of 'reality' to the extent that they present themselves as coherent and meaningful." since this is only possible within the context of experience (according to Husserl), Kohak is quite justified in concluding that "reality is not in the world or in the mind--it is in experience" (Ibid.. my emphasis). Ergo, reality is experiential. Take as an example your experience as a participant in a theatre audience. If "reality" was confined to the object-world which the sciences postulate as primary, then a gush of catsup would hardly be blood, nor the backdrop an impenetrable wall. But because we in fact experience stage props as entities which have derived their meaning from the roles and human acts portrayed in the play, we have to see that reality is neither "subjective". (arbitrary) nor "objective" (and thus a collection of neutral things-in-themselves). It is both subject-oriented (since lived experience never appears as anonymous) and intrinsically meaningful in its givenness. suppose, for instance, that you are suddenly threatened. If you are like most of us, you will experience this threat, "but ignore the experience, passing through it to posit a threatening object, and then devote [your] energies to changing the object" (Kohak, p. 92). But as long as you ignore that mode of experience which is "being-threatened," you will remain unable to come to grips with the reality of being threatened. You will remain equally unable to see that the threat is neither in the world nor in the mind, but rather in experience. Thus to understand the threat we must, as kohak puts it, "focus not on the subject, not on the world, but on the way [ (the subject) experiences (the world)]" Kohak, p.92, as in original). The point is to take experience in its lived unity, as a "way of being in and coping with the world, [of] having a world in an active sense," where the term "world" is taken to mean "something that arises in the context of the subject's active perceiving" (Kohak, p. 121). Perhaps you are about to study a child who is prone to delinquent behavior. Would it not be pure folly to explain away such behavior as a product of the child's environment (be it middle-class, underprivileged, or whatever)? "What we need is not to explain what 'made' him do it," writes Kohak,

but rather to understand what, as he understood his own acts, he chose to do. In our terminology, we need to understand what kind of noematic world he constituted about himself so that his behavior appeared appropriate to him. (Kohak, p. 137)

This type of approach contrasts sharply with our threehundred year-old habit of seeking causal explanations "out there" in the world to help us evaluate what is going on "in the mind." We are practically convinced that lived 
experience is thoroughly opaque, that experience must be observed if it is to become transparent (Kohak, p. 173). But as observed, experience "automatically becomes polarized between a disembodied observing mind and a meaningless observed movement, giving rise to the problem of their relation and of the primacy of one or the other." we lose touch with the experiencing. And if we lose touch with this, we are left unable to understand the nature of the world which the delinquent youth constituted within the context of his intentional orientation which allowed him to project his behavior as appropriate under the circumstances.

I can present no more than a skeleton of Kolnak's argument substantiating Husserl's characterization of experience as the primordial datum for knowledge acquisition. Yet it should be clear by now how Husserl goes about his project of overcoming epistemological dualism. A careful reading of Kohak's first six chapters will flesh out the project in detail and expose innumerable clues as to how the difficult terminology should be understood.

What we need to consider now is Husserl's claim that experience is Evidenz. As I suggested in my opening, Kohak presents a lucid exposition of the Husserlean project, but fails to extend any critical remarks. Yet as I also remarked, his exposition is so lucid that the obvious questions needing to be asked of Husserl rise into clear view. In turning to a characterization of Kohak's presentation of the Husserlean claim that experience is Evidenz, I hope to give expression to those questions which occurred to me.

We have spoken thus far of the primordiality of experience-as-lived, and of the I-orientation which fundamentally rounds the intelligibility inherent in experience. But how can we speak of the "ground" of something "inherent?" And furthermore, how can Husserl evade Idealism if the reality of things arises only in the constitution of these things as meaningful? I pose this second question because Husserl's answer to the first question must be that experience itself is a constitutive act. And yet he does not want us to take this to mean that experience is the product of a synthesizing activity. Rather, he wants us to see that it is experience which makes entities intelligible, that entities are only meaningful within the context of experience which is itself a source of primordial givenness grounded in "the structure of being-a-subject as such" (Kohak, p, 68 and 102). This means two things: first, that it is the act 
of "seeing" which "singles out an object," and secondly, that this act of seeing (Erlebnis) gives rise (through the constituting activity of consciousness) to "an object defined by the way it functions (the way it 'be's') in a subject's experience, in other words, an intentional object" (Kohak, p. 62). Kohak offers the example of leaping after a precious ring that is slowly rolling toward the sewer: "The lived reality is not ring + sentimental value but rather the noema, constituted in experience: this precious ring." To speak, then, of objects as "noemata" is not to speak of Kantian constructs, but rather to speak of things "as actually presenting thernselves in the context of experience" (Kohak, p. 128). This becomes the source of the Husserlian claim that experience is Evidenz, that experience is "primordially intelligible as lived." Now, the leap made here to Evidenz is justified insofar as the term is translated "evident givenness," for this is precisely what experience is for Husserl. The problems begin to arise (at least for me) when Husserl (and Kohak) introduces the possibility of "seeing" eternal validity, principles (Wesen) and Ideas (Eidos). In short, Husserl wants to argue that experience presents us with facts and essences. Indeed, if experience presented us with nothing more than facts, "reality" would be "a meaningless aggregation of fragments." Experience is intelligible only because facts "present themselves... as structured by an eidos, as making sense" (Kohak, p. 18). Thus it is "our awareness of a principle which enables us to see the raw data of our experience as intelligible objects rather than as a confusion of particulars." This "raw data" is, to use the Husserlian term, "hyletic" data, and comprises (contrary to Humean thinking) only one aspect of the primordial givenness in experience. The other aspect, which comprises our awareness of principles, is the meaning-giving act, or what Husserl calls the "noetic" phase of constitution. But unless we risk falling back into Kantianism, we must note that the noetic phase is "correlated" with the noematic phase. The noema, then, can be viewed either as the product of the meaning-giving act (which it is), or as the object-given-in-experience (which it also is). As Kohak suggests, the noetic phase is "the experience as meaning-giving," and the correlative noematic phase is "the experience as meaningful" (p. 127).

To use another one of Kohak's examples, a ship is merely a "bundle of contiguous impressions" of planks, ropes, and canvas until the hyletic data are unified into a ship by the intentional orientation which is my desire to sail. In the moment of this "purposive act," the "aggregate" of planks, rope and canvas "bobbing at anchor in the harbor becomes a ship." It takes my "purposive presence," then, to see essences (Kohak, pp. 52-3). of course, since Husserl holds that we can only perceive entities perspectivally, we mist assume that in Kohak's example one 
is not seeing "a ship" but rather "ship-ness." And yet this is not Husserl's point (nor do I take it to be Kohak's point). For Husserl says at one point in the Ideen that I do not merely see the front of the house while I stand before it; I see the house from the front. And of course this is true. But is it the case that I am grasping an eidos when I see the house from the front? or is it rather, as the later wittgenstein would say, merely the case that I perceive enough aspects of this thing before ine to be "able to go on" and grasp a house? And why must not Husserl claim that one can grasp at most a perspective of an eidos? After all, he himself says at one point in the Ideen (as quoted by Kohak) that "awareness of principles is a primordial presentive act and, as such, is analogous to sense perception" (Kohak, p. 165). For someone who claims to faithfully articulate the givenness of experience, "without any hypothetical or interpretive elaboration, without injecting anything that might have been suggested to us not by pure awareness itself but by traditional theories, aucient or modern," Husserl seems to be jumping onto the I-see-essences bandwagon without experiential justification. Kant suddenly looks to be the better respondent to Hume. But to say that I must make a judgment before I can experience a particular is hardly as satisfying as the Husserlian claim that my ability to see principles and ideas lies at the foundation of my ability to see particulars! But why is it only because I grasp principles and ideas that I am able to "understand particulars as anything more than a buzzing, booming confusion?" why, in short, is knowledge grounded in our lived-grasping of essences? For Husserl, there can be only one response: because experience is Evidenz, and Evidenz (qua seeing) involves "focusing our eyes or field glasses until the shape or color emerges clearly and unambiguously" (Kohak, p. 144, my emphasis). In short, "Evidenz demands absolute clarity, not obscure familiarity." Here we come at last to the ultimate clash between a wittgensteinian and a Husserlian: each says emphatically, "Go out into the world and look! See what is there; don't merely assume it is there. Find it!" But when tlusserl looks about himself, he sees (grasps) the concept of courage. True, Kohak remarks, he might at first see merely a series of profiles in courage, each different "but all sharing that common trait," yet if he looks long enough he will--in one "clear, sharp, and evident grasp"--see that very "principle which all instances share" (Kohak, p. 145). But is not Husserl merely presupposing that such principles exist? wittgenstein looks around and "sees" only "fainily resemblances." He asks us to think about what it is about all the games we know of which leads us to call them all by the same name: 
What is common to that all?--Don't say: "There must be something common, or they would not be called 'games'"-but look and see whether there is anything common to all.-For if you look at them you will not see anything that is common to all, but similarities, relationships, and a whole series of them at that. To repeat: don't think, but look! (Philosophical Investigations, \#66)

Wittgenstein is here questioning the fundamental Husserlian move as well as the epistemological illusion of apodicticity which seems to underlie it. Merleau-Ponty also challenges this notion of grasping the eidos. (I refer the reader to the chapter in his phenomenology of Perception entitled "The Cogito," especially pp. 387-88.) Wittgenstein would say that Husserl is being driven by a false picture, namely the search for certainty, unity, and the essential properties which are required for intelligibility to mirror exactness. Thus it is no surprise that Husserl feels we can look at a series of instances of courage and "see the principle at, metaphorically speaking, different distances, from different angles, until (we hit) on one from which (we) can focus clearly and sharply--say, an instance of courage which strikes a chord in (our) own experience" (Kohak, p. 145). I do not mean to side with wittgenstein on this issue. I merely bring up the contrast between the results of two attempts to "look and see" which Kohak fails to mention. For the Husserlian enterprise to find itself on solid ground with respect to its claim that we can experience eidetic insight, it must answer the wittgensteinian challenge. It is not enough to assume universals axe experienced, and then go on to theoretically dissect our "faculty" of experiencing into hyletic-, noetic-, and noematic-phases merely to account (in transcendental fashion) for this "ability" we (supposedly) possess. I am suggesting, of course, that a transcendental argument cannot accompany Husserl's claim to the rigorous, pre-suppositionless foundation of his enterprise. But perhaps this approach can be defended. It is clear that Kohak fails to see this as a problem worthy of notice, but this is because he feels his examples vindicate Husserl before the question can even be posed. For instance, he asks us to imagine a situation where suddenly we find ourselves exclaiming, "That's just what I needed!" He feels this exclamation shows that the speaker "knew 'in principle' what he needed long before he actually saw a 'fact' to fit that need," and, furthermore, he feels that this act of "looking for something to 'make do' presupposes a mature eidetic grasp" (Kohak, p. 22, my emphasis). So I decided to take up his challenge, imagining myself (as I have done a few times in my life) staring at a puzzle and suddenly finding that one clue which allows all the other pieces to "fall right into 
place," as the saying goes. The question to ask here is: Did I know (in any sense of the word) that this was the piece I needed to solve the puzzle? I sincerely doubt that I did. Rather, it would seem that I recognized a certain lack which was filled by something which took me by complete surprise, something which suddenly stood out as the essential figure in the ground of the puzzle-to-besolved. 'This hardly suggests a mature eidetic grasp! And yet it does seem to suggest an ante-predicative grasping of something. (And here I leave you with an I-know-notwhat.)

\section{I I}

In general, I found Idea and Experience a remarkably clear work, expecially within the context of Husserlian scholarship. Specifically, it highlights many of the serious flaws in the Boyce-Gibson translation of the Ideen, flaws which make it virtually impossible to decipher Husserl's intent. Secondly, the book indicates how Husserl's late works either illucidate, build upon, or run counter to the basic insights of the Ideen. Thirdly, Kohak's utilization of the theme of subject-orientation in his own suggestions for practical applications of Husserlian method makes it extremely clear how Husserl's transcendental ego differs from and compares to Kant's notion of the transcendental unity of apperception. Finally, I think Kohak argues strongly against the temptation to consider Husserl an Idealist. At the same time, he makes clear why Husserl cannot be classified as a realist, either. In short, these classifications do not apply to Husserl because he postulates neither that "matter" is real and "ideas" derivative, nor that "ideas" are real and "matter" is derivative. Instead, he takes experience in its "lived unity," prior to any judgmental or interpretive acts, and thus is able--it is argued--to stand "beyond" the "objective" and the "subjective" alike (Kohak, p. 172). It is the subject-as-such, not the occupant of a particular subjective posture, which is given Husserl's focus, and it is the world, not as an objectively "neutral" sphere encasing our activity, but as a context of primordial givenness "which we constitute as a meaningful whole by our (living intentional) presence" that shows forth as the "region" of our being. And of course neither this notion of subject-as-such nor the world as constituted by a subject's intentional orientation can be primary for Husserl, since experience in its givenness is primary. This much seems entirely defensable, especially given Kohak's gloss. It remains to be seen whether or not the foundation of Husserl's epistemological project can survive a rigorous examination. But it seems that we owe him the gratitude of coming to grips with his priceless notion of reality- 
as-experiential whether or not the project survives. Without such a notion in our philosophical repertoire, we are apt to remain philosophers-in-abstraction. 